Matti Salakka

FM, mediatutkimus, Turun yliopisto

\title{
"Oikea tulkinta löytyy arkistokuvista" - Seppo Rustaniusta kiinnostavat sisällissodan uhrien kohtalot
}

\begin{abstract}
Dokumenttielokuvantekijä Seppo Rustanius (s. 1943, Tampere) on käsitellyt vuoden 1918 tapahtumia, sisällissotaa ja sen jälkimaininkeja yli kymmenessä elokuvassaan. Lisäksi hän on kirjoittanut yhdessä Tuulikki Pekkalaisen kanssa Punavankileirit 1918 -kirjan.

Matti Salakka haastatteli Seppo Rustaniusta Lähikuvaan tammikuussa 2018. Keskustelua käytiin Rustaniuksen urasta ja elokuvista, dokumentti- ja arkistoelokuvan erityispiirteistä ja kotimaisesta dokumentista yleisemminkin.
\end{abstract}

\section{Matti Salakka:}

Miten sinusta tuli elokuvaohjaaja?

\section{Seppo Rustanius:}

Jumalan armosta... [naurua] Vaikea sanoa. Tätini oli tanssija, joka myös maalasi, siis aivan suvereenisti öljyväritöitä. Ehkä siinä tärpätintuoksussa oli jotain, joka veti puoleensa. Olin mä jo koululaisena innokas valokuvaaja ja perustamassa valokuvakerhoa. Mutta lukion jälkeen lähdin opiskelemaan teologiaa, ja kyllä minulla siinä vaiheessa oli pappisura tavoitteena.

Teologisten opintojeni ohella ajatukseni oli erikoistua elokuvaan. Pääsin Yleisradion radio- ja tvohjelmatoiminnan kurssille, jonka tarkoitus oli kouluttaa eri alojen ammattilaisia radion ja television ohjelmatyöhön. Kurssi toteutettiin yhdessä Tampereen yliopiston kanssa. Suoritin yliopiston lehdistö- ja tiedotusopin approbaturin ja cum laudesta praktikum-osuuden. Meitä oli muiden muassa koulut-

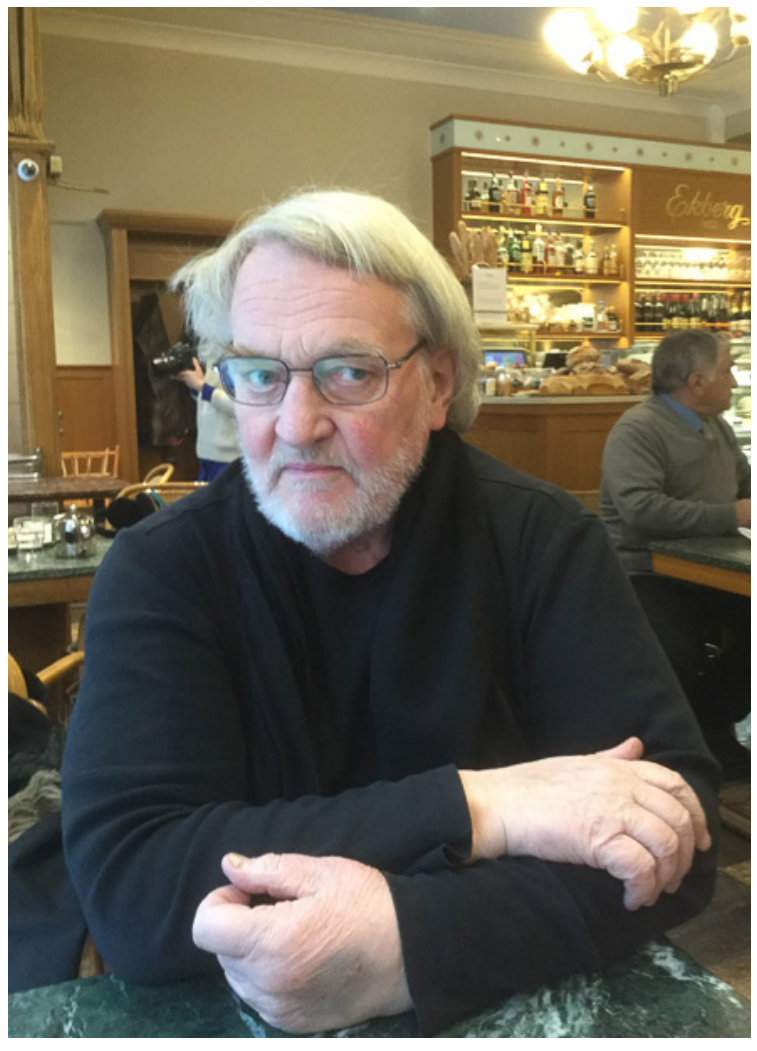

Ohjaaja Seppo Rustanius haastateltavana tammikuussa 2018. Kuva: Matti Salakka. 
tamassa Mikko Niskanen, joka oli silloin Ylen tv-toiminnan pääohjaaja. Yhtenä kannustavana opettajana toimi myös elokuva-alan konkari Harry Lewing. Tuohon aikaan luin myös paljon elokuvaa käsittelevää kirjallisuutta.

Innostuin elokuvasta yhä enemmän. Opiskelu oli siis teoreettista ja käytännöllistä - tein yhden harjoitustyön teatterikoulun näyttelijäopiskelijoiden kanssa. Itse asiassa se oli yhteen työväenlauluun toteutettu "musiikkivideo". Näissä harjoitusohjelmissa työskentelimme Ylen ammatti-ihmisten kanssa; kuvaajien, äänittäjien, lavastajien ja koko teknisen puolen kanssa. Myös radio-ohjelmatoiminnan opettajina toimi alan rautaisia ammattilaisia, esimerkiksi rakastettu Unto Miettinen opetti minua.

Lopullisesti innostuin elokuvanteosta saadessani kuulla, että Kirkkojen maailmanneuvosto jakaa erilaisia stipendejä ja apurahoja. Kyselin käytännön järjestelyistä Helsingin seurakunnista ja sain Niskaselta suosituskirjeen. Tällä stipendillä hain sitten Pariisin elokuvakorkeakouluun, mutta pahaksi onneksi vuosi sattui olemaan 1968, Euroopan hullu vuosi, jolloin kouluun ei otettu lainkaan ulkomaisia opiskelijoita.

Pariisissa sitten sihteeri, joka hoiti kirkon kansainvälisiä asioita, järjesti minulle opiskelupaikan yksityisestä elokuvakoulusta, jonka toimintaa kulttuuriministeriö valvoi. Olin siellä vuoden, ja sieltä ajauduin uralle. Työskentelin Helsingin seurakuntien elokuva- ja tv-palvelussa, sitten Kirkon tiedotuskeskuksessa, ja tätä tietä pääsin television ja elokuvan pariin.

Vähitellen minun ja kirkon tiet erkanivat, ja oikeastaan nimenomaan Sotapapitdokkarin aiheuttaman kohun takia erosin työpaikastani ja kirkosta. Kirkon tiedotusjohtaja sanoi minulle, että ympäri Suomen kirkkoherrat soittavat ja kysyvät, miksi sä pidät sellaista Rustaniusta töissä. Hän ei oikein osannut hoitaa virkaansa, ahdistui kun häntä ahdistettiin.

Seurakunnat ovat kovia paikkoja olla töissä, ja mulla oli vielä vasemmistolainen maine. Erinäisten vaiheiden jälkeen sitten erosin itse, vaikka Kirkon tiedotuskeskuksen johtokunta, silloisen arkkipiispa Vikströmin johdolla, yritti kahdesti minut erottaa - siinä kuitenkaan onnistumatta. Tällöin minulta romahti kunnioitus piispoja ja pappeja kohtaan. Totta kai on hyviäkin pappeja, mutta kirkon ideologia antaa mahdollisuuden toimia väärin ja kaksinaismoralistisesti.

Yleisradion perustamisesta alkaen on sen ja kirkon pyhä yhteys toiminut. Itse asiassa Ylen kaikki hartausohjelmat, televisio- ja radiojumalanpalvelukset, ovat julkisen palvelun periaatetta ja Yleisradiolakia noudattaessaan - samalla tulonsiirtoa kirkolle! Silloin kun minä tein ohjelmia Kirkon tiedotuskeskukselle, Yleisradio maksoi tekniikan ja kaiken, kalliit ulkolähetysautot, eli uskonnollisten ja hartausohjelmien tekeminen oli käytännössä kirkolle täysin ilmaista. Minä kiersin siis tekniikan kanssa ympäri maata tekemässä kirkollisia propagandaohjelmia.

Jossakin kohtaa aloin miettiä, kuinka pystyisin olemaan mahdollisimman paljon poissa työpaikaltani Katajanokalla. Keksin siinä, että perskules, minähän teen kaksi ohjelmaa aiheilla uskonnollisuus suomalaisessa elokuvassa. Sain ne hyväksytettyä ja vietin päivät Yleisradion filmiarkistossa valitsemassa materiaalia.

Kun jäit pois Kirkon tiedotuskeskuksesta, pääsi omien elokuviesi teko kunnolla vauhtiin. Oliko sinulle koko ajan selvää, että dokumentti on tyylilajisi?

Dokumenttielokuvassa on mielenkiintoista sekä tutkimustyö että elokuvallinen ajattelu. Tavallaan kaksi isoa aluetta ja sitten se, että tällainen kombinaatio on aina seikkailu, tutkimusmatka luovin välinein.

Olin vielä kirkolla töissä, kun tein Sotapapit. Siitä se minun ilmaisutapani vakiintui. Pengoin arkistoja todella paljon, ja elokuvan alkuhan, ekat parikymmentä minuuttia, käsittelee sisällissotaa. Siitä syttyi myös kiinnostus vuoden 1918 tapahtumiin ja se syveni pikku hiljaa. 
Ensimmäinen kokonaan sisällissotaa käsittelevä elokuvani oli 1918 sodan kuvat. Mun piti alun perin tehdä elokuva kirkon ja papiston suhteesta sisällissotaan, ja siihen oli haettuna rahoituskin. Kun Sodan kuvat oli valmis, säätiö vaati, että elokuvan pitäisi olla sellainen, jolle rahoitus on saatu, ja siksi sinne on lisätty tuo Piikki lihassa -elokuva, joka ei kyllä ihan saumattomasti asetu samaksi elokuvaksi.

Tie tuntemattomaan käsitteli venäläisten siviilien ja sotilaiden kohtaloa sisällissodassa. Siinä oli tuottajana Jarmo Jääskeläinen, jonka kanssa yhteistyö oli aina toimivaa ja helppoa. Elokuvassa oli lyhyt osio, joka ei Jääskeläisen mielestä oikein istunut kokonaisuuteen. Hän ehdotti, että tehdään tuosta ihan oma elokuva, jonka aiheena ovat punakaartin naissotilaat. Punaiset esiliinat -elokuvan jälkeen tulivatkin Punaorvot ja muut.

Tästä syntyy nyt vaikutelma, että oli puolisattumaa, että sinusta tuli vuoden 1918 tapahtumien ja sisällissodan kuvaaja?

Jos sä niin haluat sanoa, niin kyllä tuo tulkinta on ihan mahdollinen. Tuon tyyppiset letkautukset ovat sellaisia, ettei niitä koskaan itse sano, mutta huomaa kyllä, että onhan tuossa totuuden siemen. Todellakaan ei voi väittää, että olisin Pariisin elokuvakoulun jälkeen tiennyt alkavani tehdä intohimoisesti sisällissotaelokuvia. Aihe taisi löytää minut.

Ovatko elokuvasi sinun mielestäsi poliittisia elokuvia, historiadokumentteja vai kansatieteellisiä elokuvia?

Tämä voi kuulostaa hurskaalta, mutta minulla ei koskaan ollut mitään poliittista tarkoitusperää - minua kiinnostivat näiden ihmisten kohtalot. Minusta elokuvani ovat ennen kaikkea kuvauksia ihmisistä erilaisissa tilanteissa. Aivan erityisesti tajusin tämän Punaorpoja tehdessäni - kun lapsi jää kaksin äitinsä kanssa ja äiti ei saa töitä, koska on punaleski. Kiinnostuin heidän kohtaloistaan ihmisinä ja lapsina, siitä kuinka hävinneiden lapsille kävi.

Jälkeenpäin huomasin, että lähes kaikki, jotka suostuivat haastateltavaksi, olivat aikuisiässä kommunisteja. Ymmärrän hyvin heidän elämänkulkuaan, mutta alun perin minulla ei ollut tämä mielessä ollenkaan, jälkeenpäin vasta havahduin. Tässä mielessä elokuvani ovat kyllä vasiten unohdetun historian dokumentointia. Ja naiskaartilaiselokuvahan tehtiin viimeisenä hetkenä - muutama nuorena tyttönä punakaartissa ollut nainen oli yhä elossa.

Totta kai olisin voinut käsitellä myös valko-orpoja, mutta heitä oli varsin vähän ja toisaalta aihe olisi kyllä siinä levinnyt. Minua kiinnosti hävinneiden kohtalo. Onhan käsittelyn tavassa toki mukana poliittisuuttakin, mutta olisiko sitä edes voinut välttää? Suomen sisällissota oli poliittinen sota. Kyllä minua ja Pekkaa (Aine) on sitten nimitetty kommunisteiksi - Pekkaakin vain siksi, että hän on kuvannut nämä elokuvat.

\section{Miten sinusta ja Pekka Aineesta tuli työpari?}

Kuinkahan se nyt oli. Pekka oli jo kokenut kuvaaja, tehnyt paljon niin fiktiota kuin dokumenttia. Ei siinä mitään ihmeellistä ollut, Pekka valikoitui varmaan siksi, että hän oli taitava kuvaaja, jolla oli käsitystä ja kiinnostusta historialliseen dokumenttiin. Pekka on pedantti ja meidän työskentelytavat kyllä sopivat yhteen.

Sotilaspapeissa Pekka Aine ei vielä ollut mukana, Sodan kuvat oli ensimmäinen. Olisiko Jouko (Aaltonen) sanonut, että kysytään Pekkaa. Nämä aiheet koettiin aikanaan hyvin poliittiseksi, joten oli sellaisiakin tekijöitä, jotka eivät olleet kiinnostuneita tulemaan mukaan. 


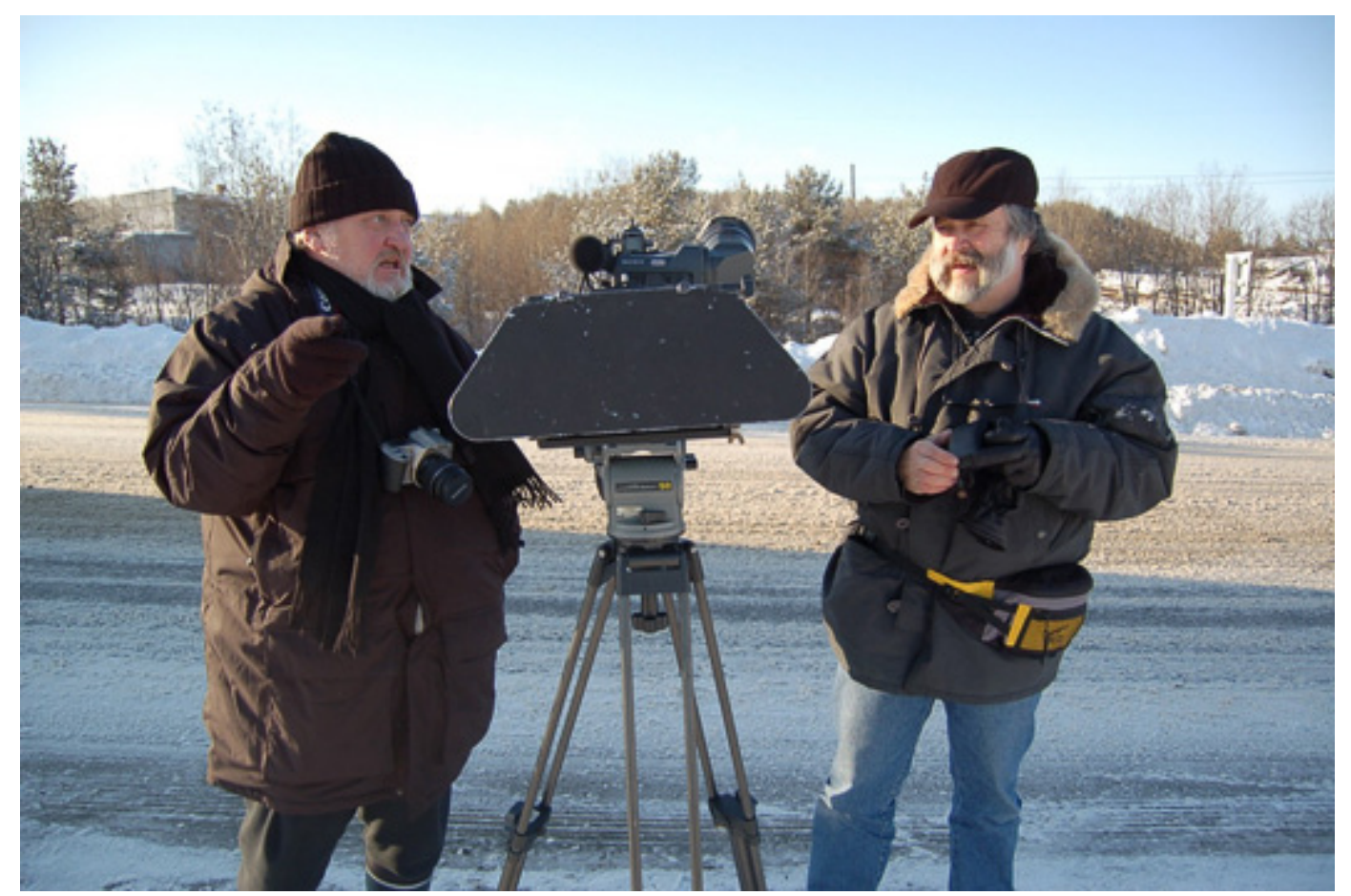

Ohjaaja Seppo Rustanius ja kuvaaja Pekka Aine kuvaamassa Kuninkaan punikit -elokuvaa vuonna 2003 Venäjän Karjalassa, Vienassa. Kuva: Tauno Romppainen, kuvan oikeudet Seppo Rustanius.

Punaorvoissa käsittelin lapsiteemaa. Nyt Jouko ehdotti lapsiteemaa, jossa ovat mukana kaikki vuoden 1918 lapset. Parasta aikaa teemmekin Sodan silmät-nimellä kulkevaa elokuvaa, joka perustuu valokuviin ja musiikkiin - hieman 1918 Sodan kuvat -leffan tyyliin. Pekka on myös tässä kuvaajana. Olemme haravoineet lähes kaikki valokuva-arkistot ja myös yksityiskokoelmia. Projekti on tosi mielenkiintoinen ja onnistuessaan vaikuttava.

Käytät paljon still-kuvia. Aiheesi huomioiden se on tietenkin pakon sanelemaa, mutta onko se myös esteettisesti jotakin, mistä pidät?

Valokuvan ja elokuvan raja on vähän turhanaikainen. Kuten kerroin, olen harrastanut valokuvausta. Mä olen aina ollut kiinnostunut kuvan olemuksesta ja valokuvan tehtävästä. Ja totta kai kyse on myös näiden elokuvien substanssista: Olli Soinio, joka leikkasi naispunakaartilaiset, sanoi, että nämähän ovat käsittämättömän hienoja kuvia jo sinällään.

Elokuvaa ei voi oikein tarkastella pysäytyskuvin, ja kuitenkin kuvan substanssi on siinä, mitä katseella löytää. Mulla sieltä materiaalista, kuvista, löytyy koko työn motiivi.

Yksittäinen kuva voi olla todella vahva - ajatellaan vaikkapa kuuluisaa kuvaa kuolleesta lapsesta mukulakivikadulla...

Siitähän saadaan koko tarina! Elokuvassa oleellista on, että hyvää kuvaa pitää näyttää riittävän pitkään. Jos kuva vain vilahtaa, se ei jää mieleen. On mietittävä oikea kesto, etteivät rytmiikka ja tempo kärsi eikä elokuvasta tule liian pitkä. Pitää löytää kompromissi näiden asioiden välillä niin, että kuvaa voidaan katsoa tarpeeksi kauan ja että se vaikuttaa. Hienot kuvat kertovat paljon. 


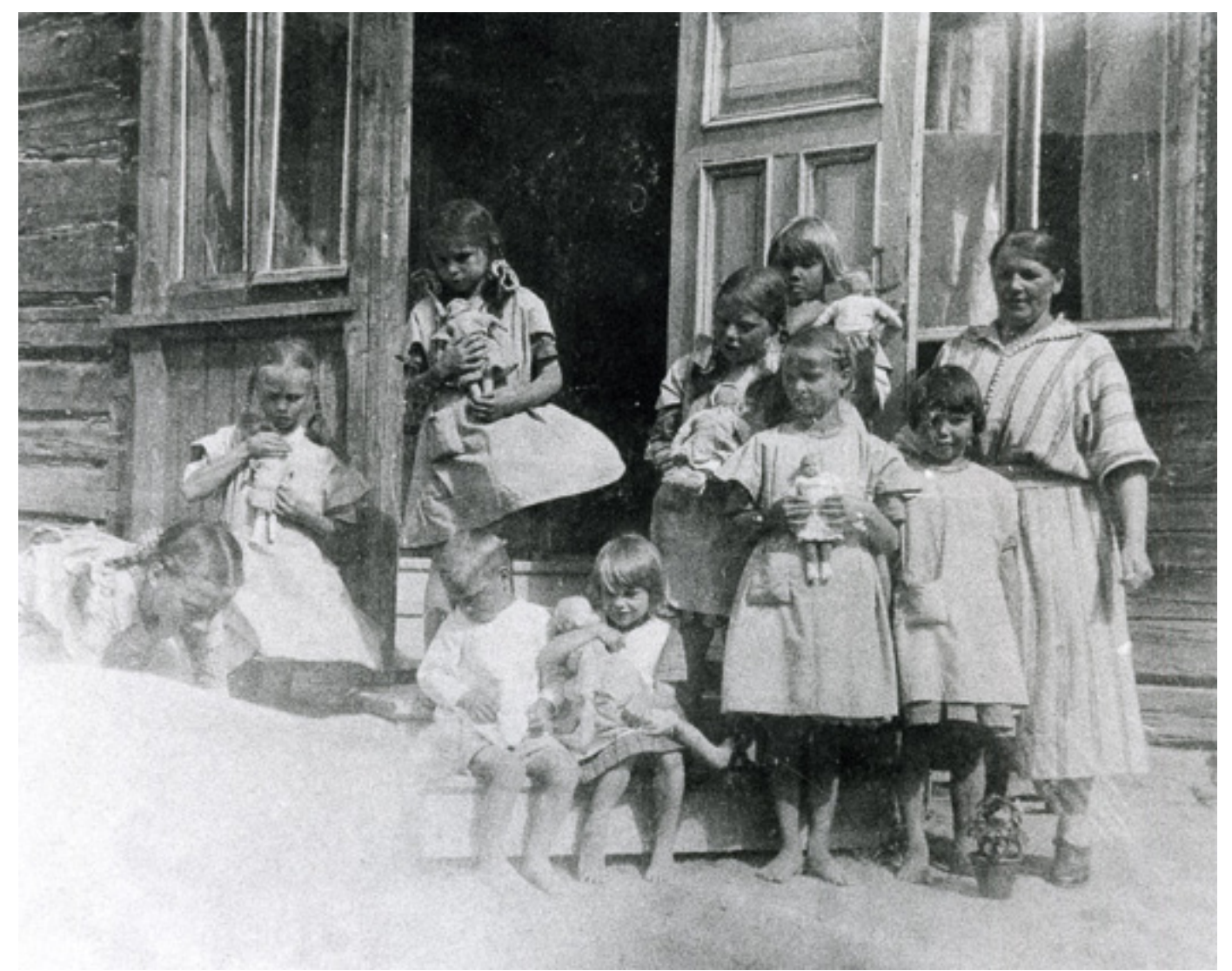

5-vuotias Meeri Kytönen orpokodissa Jämsässä, ylhäällä oven suussa. Tuntematon kuvaaja, kuva Seppo Rustaniuksen arkistosta.

Mitä dokumentti muotona sinulle merkitsee? Jos mietitään dokumentin eettisyyttä, Jouko Aaltonen on puhunut eettisyydestä kolmitasoisena kysymyksenä: tekijän suhde itseensä, elokuvan henkilöihin ja katsojiin (Lähikuva 4/2016).

Kun tein Punaorpoja, tapasin Turussa elokuvan henkilön. Hän asui Amerikassa pitkään, vaimo oli taiteilija siellä. Mies ei päässyt aikanaan veturinkuljettajakouluun, eikä armeijassa alikersantiksi, koska oli punaorpo. Hän muisteli lapsuuttaan, äitiä laittamassa maitopulloa reppuun ja sitä kuinka valkoiset hakivat isän ammuttavaksi. Hän oli muistojensa syöverissä ja alkoi itkeä. Me annoimme kameran pyöriä, mutta leikkaajalle (Timo Linnasalo) mä sanoin, että tuota ei näytetä. Se olisi aivan typerää ja moraalitonta, koska siinä kertoessa ihmisen eleistä ja ilmeistä näkyy tunnetila, se kuinka valtavan traagisista asioista on kyse.

Kaikkea ei tarvitse näyttää, ja kunnioitus haastateltavia kohtaan on yksi keskeisimpiä seikkoja niissä eettisissä ratkaisuissa, joita minä teen. Minusta henkilöiden pitää olla sellaisessa tilassa, että he tietävät, missä ovat mukana. Mulla on koko ajan ollut eettis-moraalisena ohjenuorana, että antaa katsojan päättelykyvyn ja mielikuvituksen miettiä tilanteet loppuun. Ei kaikkea shokeeraavaa tarvitse näyttää. Onhan mulla teloituskuvia paljon, mutta ne ovat valokuvia, aikalaiskuvia.

Entä sitten eettisyys käytettyä materiaalia kohtaan. Mitä vastaat sellaiseen väitteeseen, että käsittelytapa on tarkoitushakuista tai yksipuolista?

Kyllä mä joutuisin sanomaan, että joka sellaista väittää, ei ymmärrä mistään mitään. Nämä käytetyt kuvat antavat aina tietynlaiset tavat ja mahdollisuudet tulkita 
ja kertoa, ei siinä ole sataatuhatta tapaa. Kuva antaa sen oikean kuvan ja tulkinnan itsestään, muut ovat vääriä tulkintoja tai sitten kuvaa käytetään propagandatarkoituksiin tai jotakin tällaista. Se löytyy sieltä kuvasta, ja minä en käytä koskaan kuvia palvelemaan joitain omia tarkoitusperiäni.

Me ollaan puhuttu tästä leikkausvaiheessa paljon: kun kuvaa ja sen syntyhistoriaa tarpeeksi kaivaa, sieltä se löytyy kuvan varsinainen substanssi ja olemus. Ja tämä tulisi aina hakea kaikissa historiallisissa dokumenteissa, ja miksei muissakin, missä arkistomateriaalia käytetään. Tällöin elokuvantekijän tehtäväksi jää Otto Mäkilän teosta lainaten "He näkevät mitä me emme näe". Näin me ollaan Pekan kanssa yritetty elokuvissamme toimia.

Kun Lähikuva haastatteli Jouko Aaltosta (4/2016), käsiteltiin myös sitä, onko poliittisuus jotenkin pannassa kotimaisessa dokumentissa? Tämän kaltainen kuva voi myös syntyä Ilkka Kippolan ja Jari Sedegrenin kirjoista Dokumentin ytimessä (2009) ja Dokumentin utopiat (2015). Miten sinä näet tämän?

Mä kyllä yhtyisin vanhaan vasemmistosloganiin - kaikki on poliittista - ja yksityinen se vasta poliittista onkin. Minulla poliittisuus ei mielestäni erityisesti korostu, olen yrittänyt olla kansatieteellinen. Poliittisuus on toki itse aiheessa: kuten sanoin, sisällissota oli poliittinen sota.

Minulle kiinnostavampi kysymys on dokumenttielokuva versus historiantutkimus. Moni on sanonut, että Rustanius tekee historiallisia elokuvia, ja minä vastaan siihen, että vitut! Punaorvot kertoo lasten kohtaloista vuoden 1918 tapahtumiin liittyen. Siitä voi heti löytää vertailukohtia tämän päivän sotaorpoihin, pakolaisuuteen, yksinäisyyteen, osattomuuteen ja vaikka mihin teemoihin.

Tai ajatellaanpa naispunakaartilaisia. Heistä on usein puhuttu harhaanjohdettuina tai kaartin maksaman palkan takia mukaan lähteneinä. Arkostokuvissa heistä

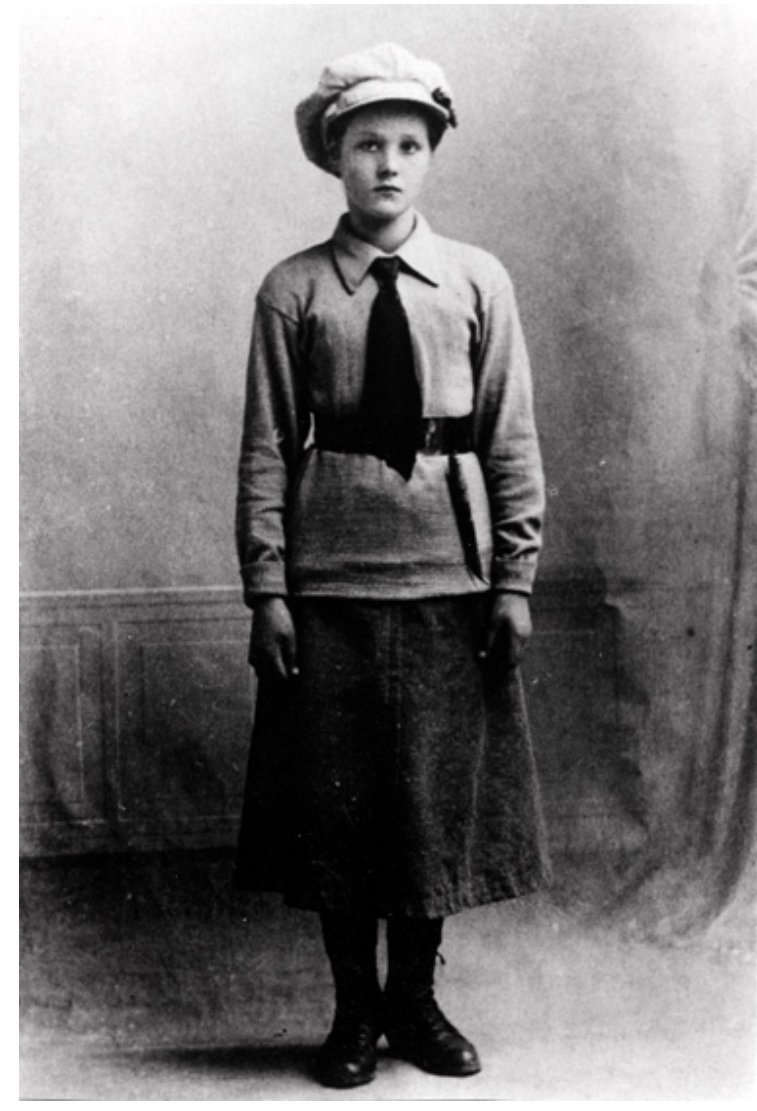

Punakaartilainen Aino Mäkinen. Tuntematon kuvaaja, kuva Seppo Rustaniuksen arkistosta. 
hehkuu kuitenkin päättäväisyys, epäitsekkyys, herkkyys ja huumorintaju. Värvätyt valkeakoskelaiset tytöt olivat harrastaneet soittoa, laulua, voimistelua ja teatteria. Tämä kaikki tapahtui kahdentoista tunnin työpäivän päälle. Ei näistä synny kuvaa mistään höynäytetyistä, ja minä totesin saman itse, kun tutustuin neljään yli 90-vuotiaaseen entiseen naiskaartilaiseen. Tätä pitäisi korostaa: kun nämä tytöt toimivat ammattiyhdistyksissä ja kävivät opintopiireissä, he olivat nykytermein osa oppivaa organisaatiota. Vaikka he olivat 16-20-vuotiaita, he olivat fiksuja likkoja. Elokuvaa tehdessäni minulla heräsi aivan suunnaton kunnioitus näitä naisia kohtaan.

\section{Elokuvasi Karjalainen kiirastuli ja Kuninkaan punikit käsittelevät sisällissotaa vain välil-} lisesti?

Lähtökohta niissäkin on sisällissodassa. Kuninkaan punikit kertoo Muurmannin legioonasta, jolla oli jopa liikkuva teatteri ja kaikenlaista kulttuuriharrastusta. Palkkansa legioonalaiset, jotka olivat sisällissodan lopulla Vienan Karjalaan paenneita punaisia, saivat Iso-Britannian hallitukselta. Kyseessä oli todella kiinnostava kuvio Suomen historiassa. Suomi oli lähellä liittyä maailmansotaan Englantia vastaan taistelemalla, ja mukana taistelemassa oli myös Saksa ja amerikkalaiset. Suomalaistaistelijat olivat pääosin entisiä punakaartilaisia.

Karjalaisen kiirastuleen saimme Petroskoista tietoomme yhden suomalaisen nimen - näitä, jotka olivat paenneet sisällissodan jälkeen Neuvosto-Venäjälle. Mies oli viulisti ja teatterilainen, joka rakastui Kanadasta muuttaneeseen suomalaissyntyiseen naiseen. Stalinin ajan vainoissa mies vietiin suoraan teatterilavalta vankileirille. Nainen oli yhä elossa ja hänellä oli miehensä viulukin tallessa.

Emme tehneet kunnon ennakkotutkimusta, vaan lähdettiin vain kuvaamaan tätä naista. Meillä oli paikallinen avustaja, joka tunsi hänet. Kun tulimme paikalle, makasi raukka sängyssä kädet täristen. Yhteyshenkilömme oli sairaanhoitaja, joka sanoi antavansa rouvalle lääkettä nyt, että hän siitä vähän piristyisi. Me rakennettiin verhon takana valot valmiiksi ja tehtiin kaikki valmistelut. Käytiin kaupungillakin tässä välissä.

Kun tulimme takaisin, rouva oli noussut ylös, ja luulin, että saamme haastattelun tehtyä. Mutta hän oli lääkityksestä jotenkin aivan ulalla, eikä saanut sanaa suustaan. Minä siinä mietin, mitä nyt tehtäisiin, koska tarinalle tämän naisen kohtalo olisi merkittävä kaikin puolin. Sitten nainen otti miehensä viulun käteensä ja melkein silitteli sitä. Minä sanoin Pekalle, että annetaan pyöriä, kuvataan tätä. Meillä oli myös kuva miehestä orkesterissaan lavalla Petroskoissa. Käytimme kuvaa ja leikattiin siitä vapisevin käsin viulua silittävään naiseen. Siitä tuli todella koskettava kohtaus, vaikka siinä ei sanottu sanaakaan.

Minusta dokumentissa noin yleisemmin on vähän unohtunut luova leikkaus, montaasi ja muu, pannaan vain kamera asemiin ja annetaan pyöriä. Ehkä tosi-tv:kin on saanut kuvittelemaan, että dokumentin teko on silkkaa tallentamista. Samalla tarinankerrontabuumissa on alettu tehdä hyvin subjektiivisia dokumentteja. Toki nykydokumentaristeissa on myös loistavia tekijöitä. Minua kiinnostavat kohtalot.

Jos mietitään vaikkapa Viipuria sisällissodan jälkimainingeissa, niin siellähän suoritettiin kansanmurha ja etninen puhdistus - eikä tästä kaikesta ole kuin sata vuotta. Jaakko Paavolaisen kirjassa (Poliittiset väkivaltaisuudet Suomessa 1918, osa 2: Valkoinen terrori, Tammi 1967) Viipurin valtauksesta vain yksi kuva, jossa valkoiset panevat miekkoja tuppeen. Tätä luultiin pitkään ainoaksi kuvaksi Viipurista, mutta sittenhän mä löysin Otavalta, kuva-arkiston johtajan omasta piirongista sellaisia tulitikkulaatikon kokoisia, T. J. Snellmanin ottamia kuvia teloituksista, valleilta ja muualta. Onneksi ne löytyivät aivan sattumalta nähtäväksi. 


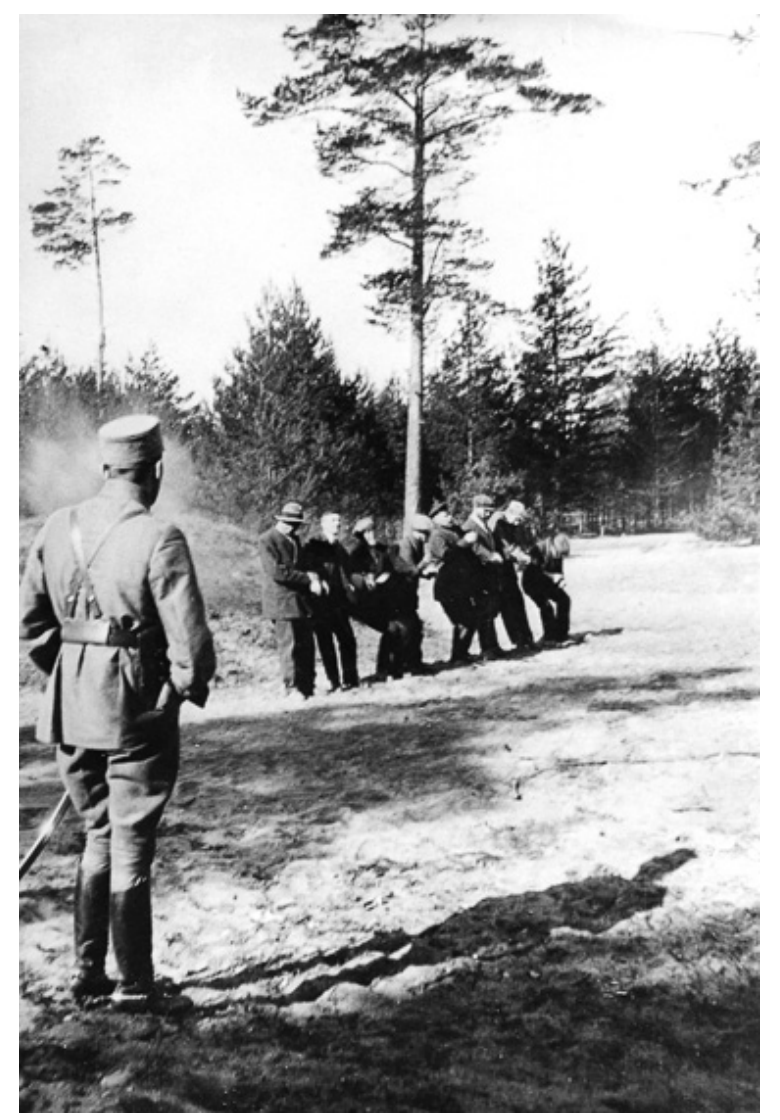

Teloitus Santahaminassa 1918. Tuntematon kuvaaja, kuva Seppo Rustaniuksen arkistosta.

Mitä sisällissodasta on vielä käsittelemättä, montakin asiaa varmasti, mutta mikä olisi tärkeintä?

Vankileiriolot on yksi keskeinen seikka, ja valtiorikosoikeuden päätökset. Kansallisarkistossa on 78000 kuulustelupöytäkirjaa. Silloin rekrytoitiin kaikki oikeustieteen ylioppilaatkin valtiorikosoikeuksiin jakamaan tuomioita. Myös monia kulttuuripersoonia oli tuomitsemassa, V. A. Koskenniemi muiden muassa. Nämä valtiorikostuomioistuimet rikkoivat sitä länsieurooppalaista oikeuskäytäntöä vastaan, että ihminen on tuomittava tekojensa eikä mielipiteidensä perusteella.

Naispunakaartilaisista kertovassa Punaiset esiliinat -elokuvassa tulee esiin yksi seikka: Kun nämä naiset olivat kuulusteltavana, tuomarin pöydällä oli pistooli kuulustelutilanteessa. Samalla kavereita vietiin vierestä ammuttavaksi, ja ylipäätään tiedossa oli armottomuus aseellisia naiskaartiin osallistuneita kohtaan. Kyllä näissä olosuhteissa ihminen saadaan kertomaan ihan mitä tahansa. Kun tällaisissa olosuhteissa kuultua kirjataan asiakirjoihin, niin kuinka paljon niistä on tutkijoille todellista käyttöä? Varmasti sanottiin, että liityin palkan takia tai että minut värvättiin väkisin. Kun on henki kysymyksessä, sitä sanoo monenmoista.

Punajääkärit ovat toinen aihe, josta haluaisin tehdä dokumentin. Punajääkärit ovat mielenkiintoinen ilmiö, jossa näkyy Suomen itsenäisyyshetkien traagisuus. Itsenäistymispyrkimykset Venäjästä heittivät maailmanpolitiikan pyörteissä ihan häränpyllyä. Työläisjohtajien poikiakin oli menossa jääkäreiksi, mutta tsaarin kukistuessa tilanne yhtäkkiä muuttui. Myös porvariston suhtautuminen itsenäistymiseen muuttui tsaarin Venäjän luhistuessa.

Olisi pitänyt ryhtyä vuosikymmeniä aiemmin tekemään näitä dokumentteja. Nyt tarvittaisiin paljon resursseja, erityisesti assistentteja tekemään taustoitusta ja en- 
nakkohaastatteluja. Mä olen tavannut tehdä melkein kaiken taustoituksen yksinäni. Se ei aina ole helppoa.

Kun tein Punaorpoja, olin tsekannut, missä heitä elää, ja soitellut ympäri Suomea. Sain Jouko Aaltosen vuokraamaan Fiat Punton, jolla ajelin pohjoiseen Iihin saakka tapaamaan ihmisiä ja tekemään ennakkotutkimusta. Jossakin vaiheessa olin kauhealla kiireellä menossa Ouluun, ja siinä matkalla tapasin vanhoja ihmisiä. Nehän tarjosivat kahvia ja ruokaa, ei se matka niin vain edennyt. Soitin useamman kerran Ouluun, että "anteeksi, nyt menee vähän pidempään, voinko vielä tulla?". Mä olin lopulta puoli kahdentoista aikaan yöllä Oulussa. Haastattelu tehtiin.

Pieksämäellä tapasin punaorvon, joka oli puhelimessa todella innokas ja hyvä tarinankertoja. Sitten kun tulimme paikalle, ei juttua irronnut lainkaan. Olisi pitänyt saada haastateltavan ensireaktio tallennettua, silloin on ihminen aidoimmillaan. Jouduin siinä vähän muistuttelemaan, että etkös muista, kun kerroit niistä kokemuksistasi puhelimessa.

Sisällissodasta ei ole syntynyt vieläkään oikein kokonaiskuvaa, sellaista jossa se nähdään yhteydessä ensimmäiseen maailmansotaan, koko Euroopan poliittiseen liikehdintään, työväenliikkeen nousuun, Saksan luhistumiseen ja niin edelleen.

\title{
Seppo Rustaniuksen valikoitu filmografia
}

\author{
2018 Sodan silmät 1918 \\ 2013 Kuninkaan punikit \\ 2008 Uhrit 1918 \\ 2007 Liikkeen mieli \\ 2005 Jään yli \\ 2002 Karjalainen kiirastuli \\ 2001 Syytteitä utopistille \\ 1999 Punaorvot valkoisessa Suomessa \\ 1997 Punaiset esiliinat \\ 1996 Tie tuntemattomaan \\ 1994 Jälkipuhdistus \\ 1991 Piikki lihassa \\ 19891918 sodan kuvat \\ 1981 Sotapapit
}

Seppo Rustaniuksen yhdessä Jouko Aaltosen kanssa ohjaama ja käsikirjoittama Sodan silmät 1918, valokuviin perustuva lyhytdokumentti, sai ensi-iltansa 15.5.2018 Yle Teemalla. Elokuva on katsottavissa Yle Areenassa: https://areena.yle.fi/1-4376796 